\title{
Cellular responses induced in vitro by pestheic acid, a fungal metabolite, in a gastric adenocarcinoma cell line (PG100)
}

J.M.C. Sousa ${ }^{1}$, L.A. Matos ${ }^{1}$, D.F.A. Alcântara ${ }^{1}$, H.F. Ribeiro ${ }^{1}$, L.S. Santos ${ }^{2}$, M.N. Oliveira ${ }^{2}$, L.C. Brito-Junior ${ }^{3,4}$, A.S. Khayat ${ }^{1}$, A.C. Guimarães ${ }^{1}$, L.A. Cunha ${ }^{1}$, R.R. Burbano ${ }^{1}$ and M.O. Bahia ${ }^{1}$

${ }^{1}$ Laboratório de Citogenética Humana, Instituto de Ciências Biológicas, Universidade Federal do Pará, Belém, PA, Brasil

${ }^{2}$ Laboratório de Produtos Naturais/Bioensaios, Instituto de Ciências Exatas e Naturais, Universidade Federal do Pará, Belém, PA, Brasil

${ }^{3}$ Laboratório de Patologia Geral, Imunopatologia e Citologia, Instituto de Ciências Biológicas, Universidade Federal do Pará, Belém, PA, Brasil ${ }^{4}$ Fundação Centro de Hemoterapia e Hematologia do Pará, Belém, PA, Brasil

Corresponding author: M.O. Bahia

E-mail:mbahia@ufpa.br

Genet. Mol. Res. 12 (4): 4106-4115 (2013)

Received March 1, 2013

Accepted August 8, 2013

Published October 1, 2013

DOI http://dx.doi.org/10.4238/2013.October.1.1

ABSTRACT. There is a constant search for new cancer treatments that are less aggressive and economically affordable. In this context, natural products extracted from plants, fungi, and microorganisms are of great interest. Pestheic acid, or dihidromaldoxin, is a chlorinated diphenylic ether extracted from the phytopathogenic fungus Pestalotiopsis guepinii (Amphisphaeriaceae). We assessed the cytotoxic, cytostatic, and genotoxic effects of pestheic acid in a gastric adenocarcinoma cell line (PG100). A decrease in clonogenic survival was observed. Pestheic acid also induced significant increases in both micronucleus and nucleoplasmic bridge frequency. However, we did not observe changes in cell cycle kinetics or apoptosis induction. Reactive oxygen 
species induced by diphenylic ethers may explain the genotoxicity and mutagenicity of pestheic acid. The absence of repair checkpoints that we observed is probably due to the fact that the PG100 cell line lacks the TP53 gene, which is common in gastric cancers. Even though pestheic acid has had a clear cytotoxic effect, the minimal inhibitory concentration was high, which shows that pestheic acid is not an active anticancer compound under these conditions.

Key words: Pestheic acid; Pestalotiopsis guepinii; Genotoxicity; Cytotoxicity

\section{INTRODUCTION}

The use of natural compounds, obtained from plants and fungi, for the treatment, cure, and prevention of diseases is one of the most ancient practices in medicine (Balunas and Kinghorn, 2005; Turolla and Nascimento, 2006). Chemotherapy is one of the main types of treatment for some malignancies. Therefore, it is extremely important to identify, extract, and synthesize compounds obtained from nature that can be used in the treatment of some neoplasias. Studies have focused on such activities in search of new substances that have the capacity to inhibit cell proliferation and metastasis (Suda et al., 2006; Yoshikawa et al., 2006).

Brazil has a rich fauna and flora, with a particular potential to produce natural compounds that can be used as medications in the prophylaxis, treatment, and cure of a wide range of pathologies, including fungal infections, diabetes, high cholesterol levels, and some kinds of cancers (Farias et al., 1997; Pinto et al., 2002; Cragg and Newman, 2005). Therefore, natural resources such as fungi are an important source of natural bioactive compounds (Wall and Wani, 1996). Some important anticancer drugs developed from fungi include those from the class of anthracyclines, bleomycins, actinomycins, and mitomycins (Culliname et al., 1994).

Aiming to evaluate the effect that some substances extracted from different fungi species found in that Amazonian flora have on neoplastic cells, our research group isolated different compounds from the endophyte species Pestalotiopsis guepinii. P. guepinii lives in association with Virola michelii, an abundant plant in the Amazon rainforest, easily found around the Belém (State of Pará) area and traditionally known as "ucuúba preta". V. michelii leaves are used by the people of this region as a medicine to ease skin rashes caused by fungi (Schultes and Holmstedt, 1968). From P. guepinii biomass, we isolated and identified different substances, including pestheic acid.

Pestheic acid, or dihydromaldoxin, is a chlorinated diphenyl ether isolated in 1996 by Adeboya et al., which acts as a plant growth regulator (Shimada et al., 2001). Its cytotoxic and genotoxic properties in eukaryote cells are still unknown. There is evidence, however, that diphenyl ethers exert different genotoxic effects in mammalian cells. Bolognesi et al. (2006) evaluated the genotoxic properties of tetrabromodiphenyl ether in fish erythrocytes using the micronucleus assay and found a statistically significant increase in micronucleus frequency, as well as an increase in the frequency of nuclear abnormalities. On the other hand, Evandri et al. (2003) did not observe any cytotoxic and/or genotoxic effects induced by the diphenyl ether BDE-99 using the chromosomal aberration test in Allium cepa.

The present study aimed to evaluate the cytotoxic, cytostatic, and mutagenic effects 
of pestheic acid in a gastric cancer cell line (PG100), since gastric cancer is a very frequent disease in the Amazonian region (Resende et al., 2006).

\section{MATERIAL AND METHODS}

\section{Pestheic acid isolation}

The $P$. guepinii fungus was statically cultured in a $4.5-\mathrm{kg}$ rice medium with $30 \%$ humidity at $28^{\circ} \mathrm{C}$ for 30 days. Methanol $(10 \mathrm{~L})$ was added to this medium and the solid material was removed by filtration. The filtrate was concentrated under reduced pressure to afford $157.3 \mathrm{~g}$ of a dark residue. This residue was suspended in $500 \mathrm{~mL} \mathrm{MeOH}: \mathrm{H}_{2} \mathrm{O}(1: 3)$ solution. The suspension was extracted successively with hexane $(3 \times 1000 \mathrm{~mL})$, dichloromethane $(3$ x $1000 \mathrm{~mL})$, and EtOAc $(3 \times 1000 \mathrm{~mL})$ and was further concentrated under vacuum. The EtOAc fraction ( $4.74 \mathrm{~g}$ ) was separated by column chromatography on silica gel using mixtures of hexane, ethyl acetate, and methanol in increasing polarities as eluents. After analysis by nuclear magnetic resonance spectroscopy of the subfractions, the hexane:EtOAc (2:8) fraction was submitted to semi-preparative reversed phase high-performance liquid chromatography (250/10 Synergi fusion $\mathrm{C} 18, \mathrm{H}_{2} \mathrm{O}: \mathrm{MeCN} 1: 1$, acidified $(1 \% \mathrm{HCOOH})$, flow rate $4.7 \mathrm{~mL} / \mathrm{min}$, $254 \mathrm{~nm}$ ) to yield $54.0 \mathrm{mg}$ pestheic acid (Figure 1). The spectral data were in agreement with the literature (Adeboya et al., 1996).

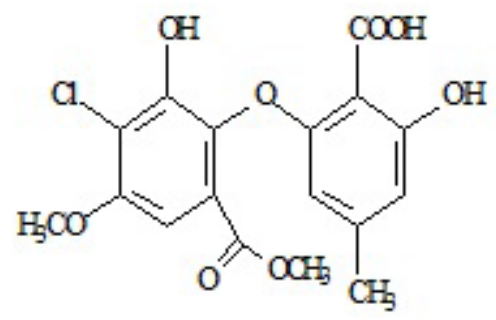

Figure 1. Chemical structure of pestheic acid.

Pestheic acid: $\mathrm{C}_{17} \mathrm{H}_{15} \mathrm{O}_{8} \mathrm{Cl}$, ESIMS m/z 381.3 [M - H],${ }^{1} \mathrm{H}$ NMR $(300 \mathrm{MHz}$; Pyridine - d5) $\delta 7.25\left(1 \mathrm{H}, \mathrm{s}, \mathrm{H}-5^{5}\right) ; 6.60(1 \mathrm{H}, \mathrm{s}, \mathrm{H}-5) ; 6.77(1 \mathrm{H}, \mathrm{s}, \mathrm{H}-3) ; 3.78,3.80$ (each 3H, s, $\left.\mathrm{CH}_{3} \mathrm{O}\right)$, $2.08\left(3 \mathrm{H}, \mathrm{s}, \mathrm{CH}_{3}\right) ;{ }^{13} \mathrm{C}$ NMR (75 MHz; Pyridine - d5) $\delta 174.5(\mathrm{COOH}), 165.9\left(\mathrm{COOCH}_{3}\right)$. 163.0 (C-2), 159.4 (C-6), 153.5 (C-4'), 150.9 (C-2'); 144.2 (C-4), 139.1 (C-1'), 124.1 (C-6'), $\left.115.7\left(\mathrm{C}^{\prime}\right)^{\prime}\right) ; 112.3(\mathrm{C}-5) ; 108.2(\mathrm{C}-3), 106.9(\mathrm{C}-1), 102.9\left(\mathrm{C}-5^{\prime}\right), 56.3\left(\mathrm{CH}_{3} \mathrm{O}\right), 52.3\left(\mathrm{CH}_{3} \mathrm{O}\right)$, $21.6\left(\mathrm{CH}_{3}\right)$.

\section{Cell culture}

The PG100 cell line was commercially obtained from the Rio de Janeiro Cell Bank. It was established after primary culture from a gastric resection of a 29-year-old male patient with gastric adenocarcinoma. Cells were grown in HAM F10 + DMEM (Sigma Chemical Co. St. Louis, MO, USA) (1:1) (v/v) supplemented with $15 \%$ fetal bovine serum (Gibco, Grand Island, NY, USA), kanamycin $(0.1 \mathrm{mg} / \mathrm{mL})$, ciprofloxacin $(0.02 \mathrm{mg} / \mathrm{mL})$, streptomycin $(0.1$ 
$\mathrm{mg} / \mathrm{mL}$ ), and penicillin $(99 \mathrm{U} / \mathrm{mL})$, and were kept in an incubator at $37^{\circ} \mathrm{C}$ and $5 \% \mathrm{CO}_{2}$.

\section{Clonogenic survival assay}

For these experiments, $1 \times 10^{6}$ cells were treated for $24 \mathrm{~h}$ with five different pestheic acid concentrations $(3.68,7.36,14.72,29.44$ and $58.88 \mu \mathrm{g} / \mathrm{mL}+$ negative control). After treatment, cells were trypsinized and 300 cells of each concentration were transferred to new duplicate culture flasks. Clones were visualized 10 days after treatment. Colonies were washed twice with PBS and then stained with Giemsa in phosphate buffer (1:30) for $50 \mathrm{~min}$. After staining, cells were washed in distilled water and clones were counted. We considered as $100 \%$ the number of colonies counted in our negative control group, and the survival fraction (SF) was calculated using the following formula:

$$
\mathrm{SF}=\frac{\text { No. of clones counted in each treatment } \mathrm{x} 100}{\text { No. of clones in negative control group }}
$$

\section{Micronucleus assay}

Cells $\left(1 \times 10^{6}\right)$ were treated with pestheic acid for $24 \mathrm{~h}$, after which cytochalasin B (Sigma Chemical Co.) $(3 \mu \mathrm{g} / \mathrm{mL})$ was added and the cells incubated for another $24 \mathrm{~h}$ at $37^{\circ} \mathrm{C}$. Cells were afterwards harvested by trypsinization and centrifuged, and slides were prepared by dropping the cell suspension directly onto pre-washed slides. Slides were stained in $3 \%$ Giemsa (Sigma Chemical Co.) in phosphate buffer (pH 6.8) for 10 min. Micronuclei were scored in 1000 binucleated cells using criteria described elsewhere (Fenech et al., 2003). We also evaluated the number of nucleoplasmic bridges in 1000 binucleated cells in each treatment. Pestheic acid concentrations used in this assay were 7.36, 14.72 and $28.44 \mu \mathrm{g} / \mathrm{mL}$. As a positive control, we used doxorubicin at a final concentration of $0.0173 \mu \mathrm{g} / \mathrm{mL}$.

\section{Assessment of changes in cell cycle kinetics and apoptosis (sub-G1 peak) induction by flow cytometry}

For these experiments, $8 \times 10^{5}$ cells were treated with $29.44 \mu \mathrm{g} / \mathrm{mL}$ pestheic acid for $24 \mathrm{~h}$ at $37^{\circ} \mathrm{C}$. Cells were then submitted to the protocol of the Cycle Test ${ }^{\text {tm }}$ Plus kit (Becton Dickinson) and subsequently read using a flow cytometer (Becton Dickinson Facs Calibur) 24, 48 , and $72 \mathrm{~h}$ after treatment. As a positive control, we used doxorubicin at a final concentration of $0.0173 \mu \mathrm{g} / \mathrm{mL}$.

\section{Statistical analysis}

The data were submitted to multiple variance analysis (ANOVA) and the post-hoc Tukey test for the clonogenic survival assay, micronucleus test, and evaluation of nucleoplasmic bridges. A $t$ test was used to assess changes in cell cycle kinetics and apoptosis induction. We also used a non-parametric test (Kruskal-Wallis) when necessary. $\mathrm{P}<0.05$ was considered statistically significant for all the parameters evaluated. BioEstat 5.0 (Ayres et al., 2007) was used for statistical analysis. 


\section{RESULTS}

\section{Clonogenic survival assay}

Clonogenic survival, assessed 10 days after treatment with pestheic acid, showed a decrease starting at the lowest concentration $(3.68 \mu \mathrm{g} / \mathrm{mL} ; 88.88 \%$ survival). Such decrease was statistically significant $(\mathrm{P}<0.05)$ at $29.44 \mu \mathrm{g} / \mathrm{mL}(53.96 \%)$ and $58.88 \mu \mathrm{g} / \mathrm{mL}(33.33 \%)$ when compared with the control group (Figure 2). Colony survival rates were 88.88, 70.63, $79.36,53.96$, and $33.33 \%$ for pestheic acid concentrations of $3.68,7.36,14.72,29.44$ and $58.88 \mu \mathrm{g} / \mathrm{mL}$, respectively. On the basis of these data, we defined the concentrations of pestheic acid to be used in the micronucleus test, i.e., 7.36, 14.72 and $29.44 \mu \mathrm{g} / \mathrm{mL}$, since such concentrations showed a survival rate over $50 \%$ when compared with the negative control.

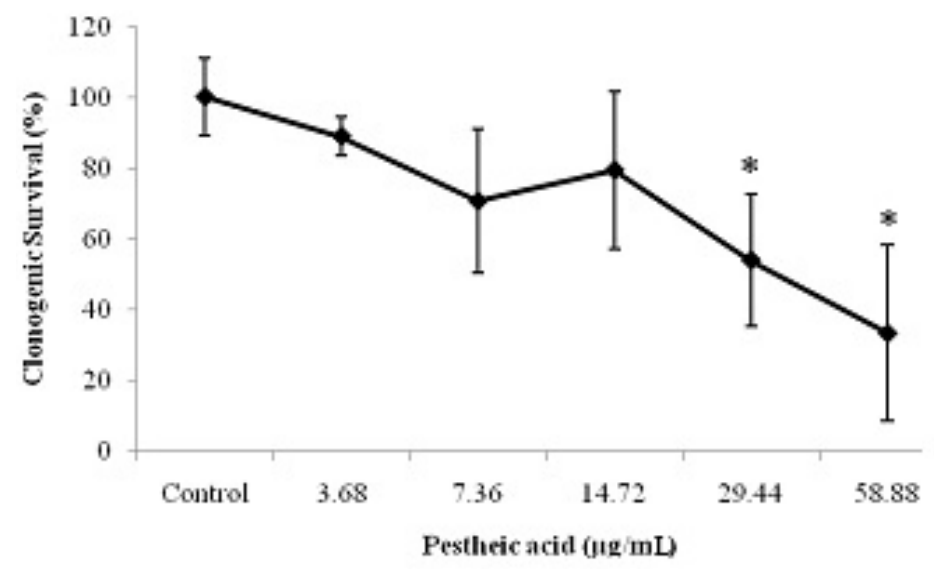

Figure 2. Clonogenic survival values observed in PG100 cell line after treatment with different concentrations ofpestheic acid. $* \mathrm{P}<0.05$ when compared to control (ANOVA). Mean of three experiments.

\section{Micronucleus assay and nucleoplasmic bridges}

Mean micronuclei per 1000 binucleated cells analyzed were 53, 51.34 and 62 for 7.36 , 14.72 and $29.44 \mu \mathrm{g} / \mathrm{mL}$ pestheic acid, respectively. The highest concentration $(29.44 \mu \mathrm{g} / \mathrm{mL})$ showed a statistically significant $(\mathrm{P}<0.05)$ increase in micronucleus $(\mathrm{MN})$ frequency when compared with the negative control (25.34 MN/1000 binucleated cells). Cells treated with doxorubicin $(0.0173 \mu \mathrm{g} / \mathrm{mL})$ had a mean micronucleus frequency of 72.67 , which was also statistically significant $(\mathrm{P}<0.05)$ when compared with the control group $(25.34 \mathrm{MN} / 1000$ binucleated cells) (Figure 3).

Mean nucleoplasmic bridges (NPB) per 1000 binucleated cells were 23, 23, and 34 for $7.36,14.72$ and $29.44 \mu \mathrm{g} / \mathrm{mL}$ pestheic acid, respectively. The highest concentration $(29.44$ $\mu \mathrm{g} / \mathrm{mL})$ induced a significant $(\mathrm{P}<0.05)$ increase in NPB frequency when compared with the control group (17 NPB/1000 binucleated cells). Treatment with doxorubicin $(0.0173 \mu \mathrm{g} / \mathrm{mL})$ induced $40 \mathrm{NPB} / 1000$ binucleated cells, which was also statistically significant $(\mathrm{P}<0.05)$ when compared with the control group (Figure 4) (17 NPB/1000 binucleated cells). 


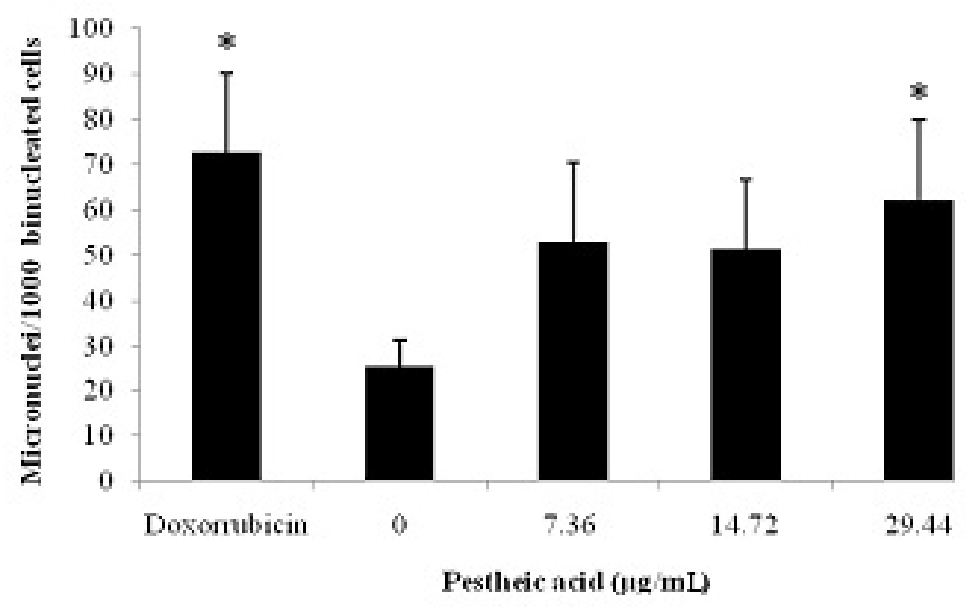

Figure 3. Micronuclei frequency observed in PG100 cell line after $24 \mathrm{~h}$ exposure to pestheic acid. $* \mathrm{P}<0.05$ when compared to control (ANOVA). Mean of three experiments.

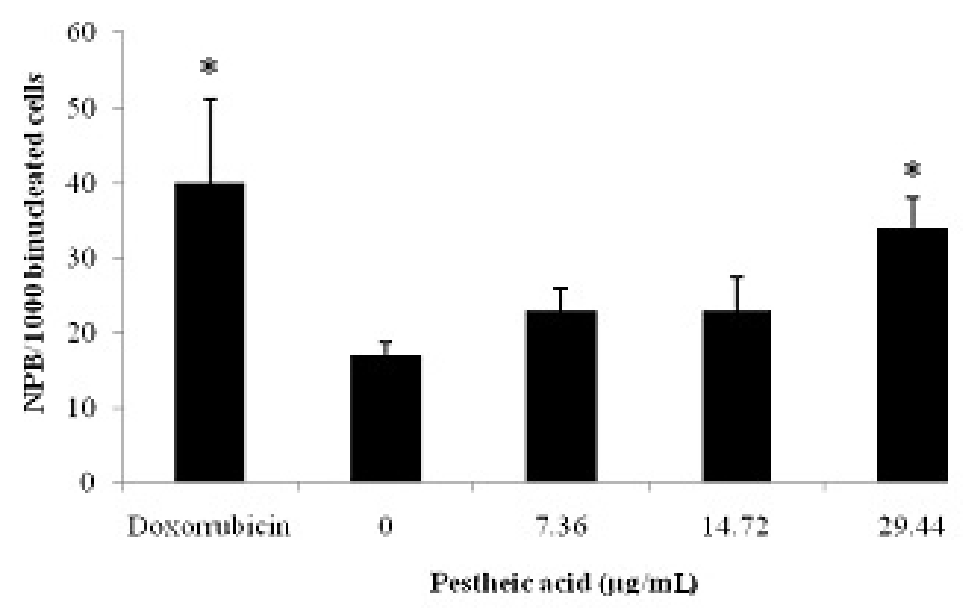

Figure 4. Nucleoplasmic bridges (NPB) frequencies observed in PG100 cell line exposed to pestheic acid for $24 \mathrm{~h}$. $* \mathrm{P}<0.05$ when compared to control (ANOVA). Mean of three experiments.

\section{Cell cycle kinetics and apoptosis (sub-G1 peak)}

To evaluate the effects of pestheic acid on cell cycle kinetics and apoptosis induction, PG100 cells were treated with $29.44 \mu \mathrm{g} / \mathrm{mL}$ pestheic acid for $24 \mathrm{~h}$. Cells were then evaluated by flow cytometry 24,48 and $72 \mathrm{~h}$ after treatment. In our experimental conditions, pestheic acid did not induce changes in cell cycle kinetics in the cell line tested (Table 1), nor did it induce apoptosis (Figure 5). Doxorubicin also failed to produce such effects (data not shown). 
Table 1. Distribution of PG100 cells treated with $29.44 \mu \mathrm{g} / \mathrm{mL}$ pestheic acid for $24 \mathrm{~h}$ in different phases of the cell cycle. Cells were analyzed at 24,48 , and $72 \mathrm{~h}$ after treatment.

\begin{tabular}{lccccccc}
\hline Time after treatment (hours) & \multicolumn{5}{c}{ Distribution of cells in different cell cycle phases (\%) } \\
\cline { 2 - 4 } & \multicolumn{3}{c}{ Control } & & \multicolumn{3}{c}{ Pestheic acid $(29.44 \mu \mathrm{g} / \mathrm{mL})$} \\
\cline { 2 - 3 } \cline { 6 - 8 } & $\mathrm{G} 1$ & $\mathrm{~S}$ & $\mathrm{G} 2 / \mathrm{M}$ & & $\mathrm{G} 1$ & $\mathrm{~S}$ & $\mathrm{G} 2 / \mathrm{M}$ \\
\hline 24 & $56.01 \pm 5.92$ & $23.15 \pm 5.74$ & $18.85 \pm 1.16$ & & $53.96 \pm 9.58$ & $23.21 \pm 8.67$ & $17.39 \pm 5.29$ \\
48 & $70.74 \pm 12.28$ & $16.81 \pm 9.45$ & $10.39 \pm 2.53$ & & $70.13 \pm 11.28$ & $13.99 \pm 8.24$ & $11.36 \pm 1.28$ \\
72 & $64.90 \pm 14.44$ & $15.74 \pm 5.53$ & $10.98 \pm 4.49$ & & $71.98 \pm 7.60$ & $13.83 \pm 4.55$ & $12.71 \pm 2.64$ \\
\hline
\end{tabular}

Data are reported as means \pm SD of three experiments.

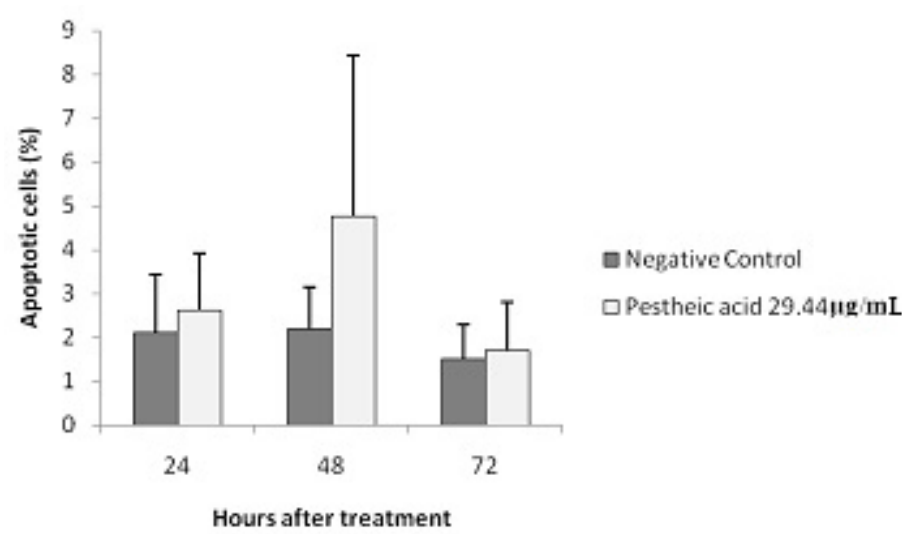

Figure 5. Percentage of apoptotic cells (sub-G1 peak) observed 24, 48, and $72 \mathrm{~h}$ after treatment with $29.44 \mu \mathrm{g} / \mathrm{mL}$ pestheic acid for $24 \mathrm{~h}$. ANOVA mean of three experiments.

\section{DISCUSSION}

The present study evaluated some cell responses (cytotoxicity, cytostaticity, and mutagenicity) induced by pestheic acid, a metabolite isolated from the fungal species $P$. guepinii, in a gastric cancer cell line (PG100). So far, no other work with this aim using such compound has been published.

Data from the micronucleus assay and NPB evaluation in PG100 cells after treatment with pestheic acid showed an increase in both parameters when compared with their respective controls (Figures 3 and 4). Genotoxic and mutagenic properties induced by other diphenyl ethers have also been observed in some studies. Barber et al. (2006) evaluated the mutagenicity of five different polybromated diphenyl ethers (PBDEs 47, 99, 153, 183, and 209) using the micronucleus assay in MCF-7 cells (human mammary carcinoma) and found a significant increase in micronucleus frequency after a $24-\mathrm{h}$ treatment with each compound at $10^{-9} \mathrm{M}$. He et al. (2008) studied the mutagenic properties of PBDE-47 in a human neuroblastoma cell line (SH-SY5Y) using the micronucleus assay, and they observed an increase in micronucleus and NPB frequencies at a concentration of $4 \mu \mathrm{g} / \mathrm{mL}$. According to these authors, a possible mechanism by which diphenyl ethers could enhance recombination or induce chromosomal aberrations is by interfering with chromatin structure and/or the proteins involved in the process.

Another possible mechanism to explain the genotoxic effects of diphenyl ethers 
would be their capacity to create reactive oxygen species (ROS), which induce DNA damage (Williams and Jeffrey, 2000). Fernie et al. (2005) analyzed the correlation between different PBDEs and oxidative stress in Falco sparverius cells, and found that PBDEs 47, 99, 100, and 153 induced oxidative stress in those cells, causing an increase in ROS production. Reistad and Mariussen (2005) investigated the effects caused by PBDE-71 on human granulocytes in vitro and observed that this compound increased ROS production in a dose-dependent manner.

The investigation on the effects of pestheic acid on PG100 cell cycle kinetics by flow cytometry showed that this metabolite does not induce changes in this parameter, which means that under the study conditions, pestheic acid does not induce cell cycle arrest for an eventual repair of cellular DNA damage. Pestheic acid did not induce apoptosis in the PG100 cell line in our experimental conditions as well. When DNA is damaged, many different pathways, the function of which is to repair the damage to minimize the occurrence of mutation, are instantly triggered. Such pathways are part of a complex signaling mechanism, each one covering a specific kind of DNA damage. Cells have basically three different responses to DNA damage caused by genotoxic agents: checkpoint activation, DNA repair, or apoptosis induction. Checkpoint activation happens when DNA damage is detected by specific proteins, such as Atm and Atr, which, along with different mediators, transduce signals to other proteins, such as Chk1 and Chk2, which activate or inactivate effector proteins. Effector proteins such p53 and cdc25 inhibit G1/S transition, S-phase progression, or G2/M transition (Sancar et al., 2004; Chen and Poon, 2008; Lazzaro et al., 2009).

In the present study, although we observed evidence of DNA damage induced by pestheic acid, we did not detect checkpoint activation in response to DNA lesions since neither cell cycle arrest nor apoptosis induction was observed (Table 1 and Figure 5). A very likely explanation for the absence of classic checkpoint activations would be PG100 possessing a mutated or deleted TP53 gene. Conventional cytogenetic studies performed by our research group using GTG banding showed a deletion in the 17p chromosomal region, where the TP53 gene is located (Ribeiro et al., 2010). Alterations in such gene are recurrent in gastric cancer (Maesawa et al., 1995; Uchino et al., 1993). Kobayashi et al. (1996) studied alterations in the TP53 locus in 67 gastric carcinomas using fluorescent in situ hybridization and found a deletion in $39 \%$ of the tumors analyzed and loss of heterozygozity of the $17 \mathrm{p} 13.3$ band. Functional loss of this gene seems to be associated with deletions of the $17 \mathrm{p} 13.3$ region and a nonsense mutation of the remainder allele, representing a starting event of the gastric carcinogenesis process and playing a crucial role in the conversion from adenomas into adenocarcinomas (Uchino et al., 1993).

The results of the clonogenic survival assay showed that pestheic acid has cytotoxic activity, inducing a decrease in cell survival in a dose-response manner (Figure 2) 10 days after the treatment, indicating that such compound induced late cell death in the PG100 cell line. The cytotoxic activities of other diphenyl ethers and their derivates in neoplastic cell lines have been observed by other authors as well. Bunyapaiboonsri et al. (2007) isolated two new glycosidic diphenyl ethers (cordyol A and B) and a diphenyl ether (cordyol C) from the fungus Cordyceps sp, and performed cytotoxic tests with all three substances in two different cell lines (BC - breast cancer, and NCI-H187 - lung cancer). They found that only cordyol C had moderate cytotoxic activity against both cell lines, with an $\mathrm{IC}_{50}$ of $8.65 \mu \mathrm{g} / \mathrm{ml}$ and $3.75 \mu \mathrm{g} /$ $\mathrm{mL}$ for BC and NCI-H187, respectively. Wang et al. (2006) investigated the cytotoxic activity of a new diphenyl ether called Neoplaeter isolated from the cultivated fungus Neoplaconema 
napellum IFB-E016. Using the MTT assay, the authors observed a significant cytotoxic activity caused by Neoplaeter in the cell line KB (epidermoid nasopharyngeal cancer) with an $\mathrm{IC}_{50}$ of $13 \mu \mathrm{g} / \mathrm{mL}$. In the present study, the $\mathrm{IC}_{50}$ found was $50.5 \mu \mathrm{g} / \mathrm{mL}$, which shows that in our conditions pestheic acid is not a potent anticancer compound. Compounds exhibiting $\mathrm{IC}_{50}$ values $<4 \mu \mathrm{g} / \mathrm{mL}$ are considered potent (Hall et al., 1999).

As reported above, pestheic acid cytotoxicity was not induced by apoptosis; therefore, the cell death observed in our results may have been induced by another mechanism not assessed by this study, such as necrosis. According to Bursch et al. (2008), necrosis results from violent environmental perturbation leading to the collapse of internal homeostasis, cell swelling, and eventually cell lysis. In fact, if diphenyl ethers enhance ROS production, cell death by necrosis should not be ruled out, since the cell membrane, cell proteins, and DNA are targets for ROS attack, which culminates in the disruption of organelle and cell integrity (Festjens et al., 2006; He et al., 2008). Birchmeier et al. (2005) observed that necrosis was the main responsible factor for the cytotoxicity observed in human thymocytes exposed to $100 \mu \mathrm{g} /$ mL PBDEs 47 and 99.

The present study showed the ability of pestheic acid to induce cytotoxic and mutagenic alterations in the gastric cancer cell line PG100. Even though the cytotoxicity observed in our experimental conditions does not deem the use of pestheic acid as a compound with anticancer activity, our findings demonstrate a cell behavior in the presence of a compound whose cytotoxic and genotoxic properties are completely unknown in eukaryotic cells.

\section{ACKNOWLEDGMENTS}

Research supported by FAPESPA (Fundação de Amparo à Pesquisa do Estado do Pará; Grant \#309083/2009). The authors are grateful to CNPq for awarding a scholarship to JMCS.

\section{REFERENCES}

Adeboya MO, Edwards RL, Lassoe T, Maitland DJ, et al. (1996). Metabolites of the higher fungi. Maldoxin, maldoxone, dihydromaldoxin, isodihydromaldoxin and dechlorodihydromaldoxin. A spirocyclohexadienone, a depsidone and three diphenyl ethers: keys in the depsidone biosynthetic pathway from a member of the fungus genus Xylaria. $J$. Chem. Soc. Chem. Commun. 1: 1419-1425.

Ayres M, Ayres JR, Ayres M and Santos AS (2007). Bioestat 5.0. Belém. Sociedade Civil Mamirauá, 364.

Balunas MJ and Kinghorn AD (2005). Drug discovery from medicinal plants. Life Sci. 78: 431-441.

Barber JL, Walsh MJ, Hewitt R, Jones KC, et al. (2006). Low-dose treatment with polybrominated diphenyl ethers (PBDEs) induce altered characteristics in MCF-7 cells. Mutagenesis 5: 351-360.

Birchmeier KL, Smith KA, Passino-Reader DR, Sweet LI, et al. (2005). Effects of selected polybrominated diphenyl ether flame retardants on lake trout (Salvelinus namaycush). Environ. Toxicol. Chem. 24: 1518-1522.

Bolognesi C, Perrone E, Roggieri P, Pampanin DM, et al. (2006). Assessment of micronuclei induction in peripheral erythrocytes of fish exposed to xenobiotics under controlled conditions. Aquat. Toxicol. 78 (Suppl 1): S93-S98.

Bunyapaiboonsri T, Yoiprommarat S, Intereya K and Kocharin K (2007). New diphenyl ethers from the insect pathogenic fungus Cordyceps sp. BCC 1861. Chem. Pharm. Bull. 55: 304-307.

Bursch W, Karwan A, Mayer M, Dornetshuber J, et al. (2008). Cell death and autophagy: cytokines, drugs, and nutritional factors. Toxicology 254: 147-157.

Chen Y and Poon RY (2008). The multiple checkpoint functions of CHK1 and CHK2 in maintenance of genome stability. Front. Biosci. 13: 5016-5029.

Cragg GM and Newman DJ (2005). Plants as a source of anti-cancer agents. J. Ethnopharmacol. 100: 72-79.

Cullinane C, Cutts SM, van Rosmalen A and Phillips DR (1994). Formation of adriamycin-DNA adducts in vitro. Nucleic Acids Res. 22: 2296-2303. 
Evandri MG, Mastrangelo S, Costa LG and Bolle P (2003). In vitro assessment of mutagenicity and clastogenicity of BDE99, a pentabrominated diphenyl ether flame retardant. Environ. Mol. Mutagen. 42: 85-90.

Farias RA, Rao VS, Viana GS, Silveira ER, et al. (1997). Hypoglycemic effect of trans-dehydrocrotonin, a nor-clerodane diterpene from Croton cajucara. Planta Med. 63: 558-560.

Fenech M, Chang WP, Kirsch-Volders M, Holland N, et al. (2003). HUMN project: detailed description of the scoring criteria for the cytokinesis-block micronucleus assay using isolated human lymphocyte cultures. Mutat. Res. 534: 65-75.

Fernie KJ, Shutt JL, Mayne G, Hoffman D, et al. (2005). Exposure to polybrominated diphenyl ethers (PBDEs): changes in thyroid, vitamin A, glutathione homeostasis, and oxidative stress in American kestrels (Falco sparverius). Toxicol. Sci. 88: 375-383.

Festjens N, Vanden Berghe T and Vandenabeele P (2006). Necrosis, a well-orchestrated form of cell demise: signalling cascades, important mediators and concomitant immune response. Biochim. Biophys. Acta 1757: 1371-1387.

Hall IH, Peaty NJ, Henry JR, Easmon J, et al. (1999). Investigations on the mechanism of action of the novel antitumor agents 2-benzothiazolyl, 2-benzoxazolyl, and 2-benzimidazolyl hydrazones derived from 2-acetylpyridine. Arch. Pharm. 332: 115-123.

He W, He P, Wang A, Xia T, et al. (2008). Effects of PBDE-47 on cytotoxicity and genotoxicity in human neuroblastoma cells in vitro. Mutat. Res. 649: 62-70.

Kobayashi M, Kawashima A, Mai M and Ooi A (1996). Analysis of chromosome 17p13 (p53 locus) alterations in gastric carcinoma cells by dual-color fluorescence in situ hybridization. Am. J. Pathol. 149: 1575-1584.

Lazzaro F, Giannattasio M, Puddu F, Granata M, et al. (2009). Checkpoint mechanisms at the intersection between DNA damage and repair. DNA Repair 8: 1055-1067.

Maesawa C, Tamura G, Suzuki Y, Ogasawara S, et al. (1995). The sequential accumulation of genetic alterations characteristic of the colorectal adenoma-carcinoma sequence does not occur between gastric adenoma and adenocarcinoma. J. Pathol. 176: 249-258.

Pinto C, Silva DHS, Bolzani VS, Lopes NP, et al. (2002). Produtos naturais: atualidade, desafios e perspectivas . Quim. Nova 25: 45-61.

Reistad T and Mariussen E (2005). A commercial mixture of the brominated flame retardant pentabrominated diphenyl ether (DE-71) induces respiratory burst in human neutrophil granulocytes in vitro. Toxicol. Sci. 87: 57-65.

Resende ALS, Mattos IE and Koifman S (2006). Mortalidade por câncer gástrico no estado do Pará, 1980-1997. Arquiv. Gastroenterol. 3: 247-251.

Ribeiro HF, Alcantara DF, Matos LA, Sousa JM, et al. (2010). Cytogenetic characterization and evaluation of c-MYC gene amplification in PG100, a new Brazilian gastric cancer cell line. Braz. J. Med. Biol. Res. 43: 717-721.

Sancar A, Lindsey-Boltz LA, Unsal-Kacmaz K and Linn S (2004). Molecular mechanisms of mammalian DNA repair and the DNA damage checkpoints. Annu. Rev. Biochem. 73: 39-85.

Schultes RE and Holmstedt R (1968). The vegetal ingredients of the Myristicaceae snuffs of the Northwest Amazon. Rhodera 70: 113-160.

Shimada I, Takahashi T, Kawano Y and Kimura Y (2001). Chloroisosulochrin, chloroisosulochrin dehydrate, and pestheic acid, plant growth regulators, produced by Pestalotiopsis theae. Z Naturforsch. C. 56b: 797-803.

Suda T, Katoh M, Hiratsuka M, Takiguchi M, et al. (2006). Heat-regulated production and secretion of insulin from a human artificial chromosome vector. Biochem. Biophys. Res. Commun. 340: 1053-1061.

Turolla MSR and Nascimento ES (2006). Informações toxicológicas de alguns fitoterápicos utilizados no Brasil (Art). Braz. J. Pharmacol. 42: 289-306.

Uchino S, Noguchi M, Ochiai A, Saito T, et al. (1993). p53 mutation in gastric cancer: a genetic model for carcinogenesis is common to gastric and colorectal cancer. Int. J. Cancer. 54: 759-764.

Wall ME and Wani MC (1996). Camptothecin and taxol: from discovery to clinic. J. Ethnopharmacol. 51: 239-253.

Wang FW, Ye YH, Chen JR, Wang XT, et al. (2006). Neoplaether, a new cytotoxic and antifungal endophyte metabolite from Neoplaconema napellum IFB-E016. FEMS Microbiol. Lett. 261: 218-223.

Williams GM and Jeffrey AM (2000). Oxidative DNA damage: endogenous and chemically induced. Regul. Toxicol. Pharmacol. 32: 283-292.

Yoshikawa K, Kajiwara K, Morioka J, Fujii M, et al. (2006). Improvement of functional outcome after radical surgery in glioblastoma patients: the efficacy of a navigation-guided fence-post procedure and neurophysiological monitoring. J. Neurooncol. 78: 91-97. 